\title{
VOCALIZATION DATA MINING FOR ESTIMATING SWINE STRESS CONDITIONS
}

\author{
MARTA MOI ${ }^{1}$, IRENILZA DE A. NÄÄ ${ }^{2}$, FABIANA R. CALDARA ${ }^{3}$, IBIARA C. DE L. \\ ALMEIDA PAZ ${ }^{4}$, RODRIGO G. GARCIA ${ }^{5}$, ALEXANDRA F. S. CORDEIRO ${ }^{6}$
}

\begin{abstract}
This study aimed to identify differences in swine vocalization pattern according to animal gender and different stress conditions. A total of 150 barrow males and 150 females (Dalland $^{\circledR}$ genetic strain), aged 100 days, were used in the experiment. Pigs were exposed to different stressful situations: thirst (no access to water), hunger (no access to food), and thermal stress (THI exceeding 74). For the control treatment, animals were kept under a comfort situation (animals with full access to food and water, with environmental THI lower than 70). Acoustic signals were recorded every 30 minutes, totaling six samples for each stress situation. Afterwards, the audios were analyzed by Praat $^{\circledR}$ 5.1.19 software, generating a sound spectrum. For determination of stress conditions, data were processed by WEKA ${ }^{\circledR} 3.5$ software, using the decision tree algorithm C4.5, known as J48 in the software environment, considering cross-validation with samples of $10 \%$ (10-fold cross-validation). According to the Decision Tree, the acoustic most important attribute for the classification of stress conditions was sound Intensity (root node). It was not possible to identify, using the tested attributes, the animal gender by vocal register. A decision tree was generated for recognition of situations of swine hunger, thirst, and heat stress from records of sound intensity, Pitch frequency, and Formant 1.
\end{abstract}

KEYWORDS: sound intensity, sound attributes, animal welfare.

\section{MINERAÇÃO DE DADOS DE VOCALIZAÇÃO PARA ESTIMATIVA DE CONDIÇÕES DE ESTRESSE DE SUÍNOS}

RESUMO: Este trabalho teve o objetivo de identificar diferenças no padrão de vocalização em função do sexo dos animais e diferentes situações de estresse. Foram utilizados 150 animais machos castrados e 150 fêmeas (linhagem Dalland ${ }^{\circledR}$ ), com 100 dias de idade. Os suínos foram submetidos a diferentes situações de estresse: sede (animais sem acesso à água), fome (suínos sem acesso ao alimento), estresse térmico (ITU superior a 74) e BEA (animais com alimento e água, com ITU abaixo de 70). Foram registrados os sinais acústicos a cada 30 minutos, totalizando seis coletas para cada situação de estresse. Posteriormente, os áudios foram analisados pelo software Praat ${ }^{\circledR}$ 5.1.19, gerando um espectro sonoro. Para a determinação das condições de estresse, os dados foram processados no programa computacional WEKA ${ }^{\circledR} 3.5$, utilizando o algoritmo de árvore de decisão C4.5, conhecido como J48 no ambiente do programa computacional WEKA ${ }^{\circledR}$, considerando validação cruzada com amostras de 10\% (10-fold cross-validation). De acordo com a Árvore de Decisão, o atributo acústico mais importante para a classificação das condições de estresse foi a Intensidade do som (nó raiz). Não foi possível identificar o sexo dos animais pelo registro vocal, utilizando os atributos testados. Foi gerada uma árvore de decisão para reconhecimento de situação de fome, sede e estresse térmico em suínos, a partir de registros da intensidade do som, da frequência de Pitch e da Formante 1.

PALAVRAS-CHAVE: intensidade do som, atributos sonoros, bem-estar animal.

\footnotetext{
${ }^{1}$ Zootecnista, M.Sc. em Zootecnia, Faculdade de Ciências Agrárias-UFGD, Rod Dourados - Itahum, km 12, Dourados - MS, Brasil, Fone: (+55 67) 3410-2500, mar_moi@hotmail.com

${ }^{2}$ Eng ${ }^{\mathrm{a}}$. Civil, Pesquisadora Visitante Sênior, Faculdade de Ciências Agrárias-UFGD, Dourados - MS, Brasil, irenilza@gmail.com

${ }^{3}$ Zootecnista, Profa. Dra., Faculdade de Ciências Agrárias-UFGD, Dourados - MS, Brasil, fabianacaldara@ufgd.edu.br

${ }^{4}$ Zootecnista, Profa. Dra., Faculdade de Ciências Agrárias-UFGD, Dourados - MS, Brasil, ibiarapaz@gmail.com

${ }^{5}$ Zootecnista, Prof. Doutor, Faculdade de Ciências Agrárias-UFGD, Dourados - MS, Brasil, rodrigogarcia@ufgd.edu.br

${ }^{6}$ Zootecnista, Dra. em Eng ${ }^{a}$ Agrícola, Faculdade de Eng ${ }^{a}$ Agrícola-UNICAMP, Campinas - SP, Brasil, Fone:(+55 19) $3251-1039$ Recebido pelo Conselho Editorial em: 29-7-2013

Aprovado pelo Conselho Editorial em: 20-12-2013
} 


\section{INTRODUCTION}

Pork is the most consumed meat in the world, and the production systems have been searching for an automated way to estimate animal welfare in the livestock, since this is an important demand from the overseas market. Among ways to audit animal welfare, there is monitoring of their behavior and social interactions (BAPTISTA et al., 2011; SPINKA, 2012), observation of health and rearing conditions (BAPTISTA et al., 2011; CALDARA et al., 2012), and monitoring of their vocalization expressed during production phases (MARX et al., 2003; SAMPAIO et al., 2007; NÄÄS et al., 2008).

Vocalization is an objective and noninvasive tool that may evidence lack of herd welfare based on the release of distinct vocal patterns (NÄÄS et al., 2008). MARX et al. (2003) characterized different types of swine sounds and identified diverse parameters of emitted energy, frequency, and duration. Animal vocalization is, thus, an expression of its current condition, and may occur spontaneously or, yet, be the result of an event, such as hunger and pain; for this reason, it became an important tool to assess animal welfare (DÜPJAN et al., 2008). There is evidence that each animal has individual vocalization characteristics. Animals use vocalization as a means of communication among individuals of the same species (GRANDIN, 1998). Female pigs express a composite frequency of grunts as identified by SCHRADER \& TODT (1998).

For sound data analysis, it is important to use intelligent techniques of data processing, which can help to identify stressful situations. These techniques are able to transform data into relevant information and knowledge, providing support for decision making. The techniques of data mining have shown promising results for knowledge increase on animal production (NÄÄS et al., 2008; CORDEIRO et al., 2012).

This study aimed to identify differences in swine vocalization pattern according to gender and exposure to diverse stress conditions.

\section{MATERIAL AND METHODS}

The experiment was conducted at a commercial swine farm in April 2012, located in the northwest of Rio Grande do Sul State, Brazil (275'23" S, 5302'21" W, mean altitude of 385 m). According to Köeppen classification, the climate in the region is humid subtropical.

We used 150 surgically castrated males and 150 females (Dalland ${ }^{\circledR}$ genetic strain), aged 100 days (growth phase), distributed in 10 pens. Pigs were housed in sheds of east-west solar orientation, ceiling height of $3.0 \mathrm{~m}$, side walls of $1 \mathrm{~m}$ height with curtains at side openings, and fiber cement tiles $(0.006 \mathrm{~m})$. Sheds had 10 pens of $30 \mathrm{~m}^{2}$ each, with 30 animals allocated in each pen. The floor was built in concrete with a running water channel of $0.05 \mathrm{~m}$ at the end of each pen. Nipple drinkers were also placed at the end (three per pen). The automatic feeder had the capacity to feed six pigs. At the shed outside, there was a bush line with the aim to provide shade on the shed upper part (roof).

Environmental data (temperature and relative humidity) were recorded every 30 min using a digital thermo-hygrometer. Values of wet bulb temperature (WBT, ${ }^{\circ} \mathrm{C}$ ) were calculated using mean values of dry bulb temperature (DBT, ${ }^{\circ} \mathrm{C}$ ) and relative humidity $(\mathrm{RH}, \%)$, using Psicrom ${ }^{\circledR}$ software (RORIZ, 2003). The Temperature-Humidity Index (THI) was calculated using eq.(1), as described by ROLLER \& GOLDMAN (1969):

$$
\mathrm{THI}=0.45 \mathrm{WBT}+1.35 \mathrm{DBT}+32
$$

Animals were exposed to different stressful managements, such as thirst (no access to water), hunger (no access to fodder), and thermal stress (TS, THI $\geq 74$ ); welfare conditions (WC, animals had continuous access to fodder and water, and were reared under $\mathrm{THI}<73$ ).

Stressful situations by hunger and thirst were determined after a period of 11 hours of fasting, for both cases; data recording began after this period. 
Acoustic signals were recorded every $30 \mathrm{~min}$, totaling six samples for each stress exposure. Acoustic recording was performed with a unidirectional microphone Marantz ${ }^{\circledR}$ PMD 660. The microphone was positioned at $1 \mathrm{~m}$ above the pigs, at the pen central area, and connected to a recorder. Recorded signals were digitalized using a frequency of up to 44,100 Hz, during $3 \mathrm{~min}$.

After finishing the swine vocalization recording, sound signals were downloaded to a computer. Each pen provided the record of a sequential range of "screams and grunts" (vocalizations). Subsequently, the audios were analyzed using Praat ${ }^{\circledR} 5.1 .19$ software, and the acoustic parameters were extracted using Fourier transform, generating a sound spectrum. The attributes generated by the software revealed the signal energy $\left(\mathrm{Pa}^{2 *} \mathrm{~s}\right)$, maximum and minimum amplitudes $(\mathrm{Pa})$, pitch frequency $(\mathrm{Hz})$, sound intensity $(\mathrm{dB})$, and four levels of formants (F1, F2, F3, and F4) that are also called harmonic ( $\mathrm{Hz})$.

To determine stress conditions, data were processed using WEKA ${ }^{\circledR}$ (3.5) software, with J48 algorithm, and considering cross-validation with samples of $10 \%$ (10-fold cross-validation). The attributes used in data mining processing are described in Table 1, and the target attribute was the stress condition.

TABLE 1. Attributes used for data mining.

\begin{tabular}{lll}
\hline \multicolumn{1}{c}{ Attribute } & \multicolumn{1}{c}{ Unit } & \multicolumn{1}{c}{ Description } \\
\hline Gender & - & Male or Female \\
Time & - & $1 ; 2 ; 3 ; 4 ; 5$ and 6 \\
Stress conditions & $\mathrm{Pa}^{2 *} \mathrm{~s}$ & WC, TS, pain, thirst, and hunger \\
Signal energy & $\mathrm{S}$ & Energy emitted by the sound wave \\
Signal duration & $\mathrm{Pa}$ & Duration of the sound wave \\
Maximum amplitude & $\mathrm{Pa}$ & Maximum amplitude of the sound wave \\
Minimum amplitude & $\mathrm{dB}$ & Minimum amplitude of the sound wave \\
Intensity & Hertz & Intensity of the sound wave \\
Pitch frequency & Hertz & Determine the sound wave dimension \\
Formant 1 & Hertz & Frequency of formant 1 \\
Formant 2 & Hertz & Frequency of formant 2 \\
Formant 3 & Hertz & Frequency of formant 3 \\
Formant 4 & & Frequency of formant 4 \\
\hline
\end{tabular}

\section{RESULTS AND DISCUSSION}

The Decision Tree (Figure 1), obtained by using the J48 algorithm, had 77.66\% accuracy and Kappa of 0.62. According to the Decision Tree result, the most important acoustic attribute for classification of the studied stress conditions was sound intensity (root node).

For noise intensity lower than or equal to $73.87 \mathrm{~dB}$, there was an indication that animals were under a welfare situation; on the other hand, for sound intensity ranging from more than 73.87 to $80.18 \mathrm{~dB}$, we understood that animals were thirsty. For noise intensity higher than $80.18 \mathrm{~dB}$, it was necessary to check the pitch frequency. Thus, for pitch frequency higher than $276.71 \mathrm{~Hz}$, there was an indication that animals were under heat stress. For pitch frequency ranging from 276.71 to $212.87 \mathrm{~Hz}$, we estimated that animals were hungry. From pitch frequency higher than $212.87 \mathrm{~Hz}$, Formant 1 needed to be verified. In this case, when Formant 1 was greater than $1,066.4 \mathrm{~Hz}$, there was an indication that animals were thirsty, while for Formant 1 lower than or equal to 1,066.4 Hz, animals may have been hungry.

In a study on piglets during farrowing, RISI (2010) compared acoustic characteristics of piglet vocalizations between arthritis and health. Healthy piglets emitted vocalizations with greater 
intensity $(79.76 \mathrm{~dB})$ than arthritic animals $(78.15 \mathrm{~dB})$. This feature is interpreted by sound intensity (dB); the explanation for its occurrence is also related to the animal performance in stimulating air expulsion through the respiratory tract, promoting the vibration of vocal cords (RISI, 2010). The use of sound intensity as a determinant factor for welfare estimate was efficient in a study carried out by NÄÄS et al. (2008).

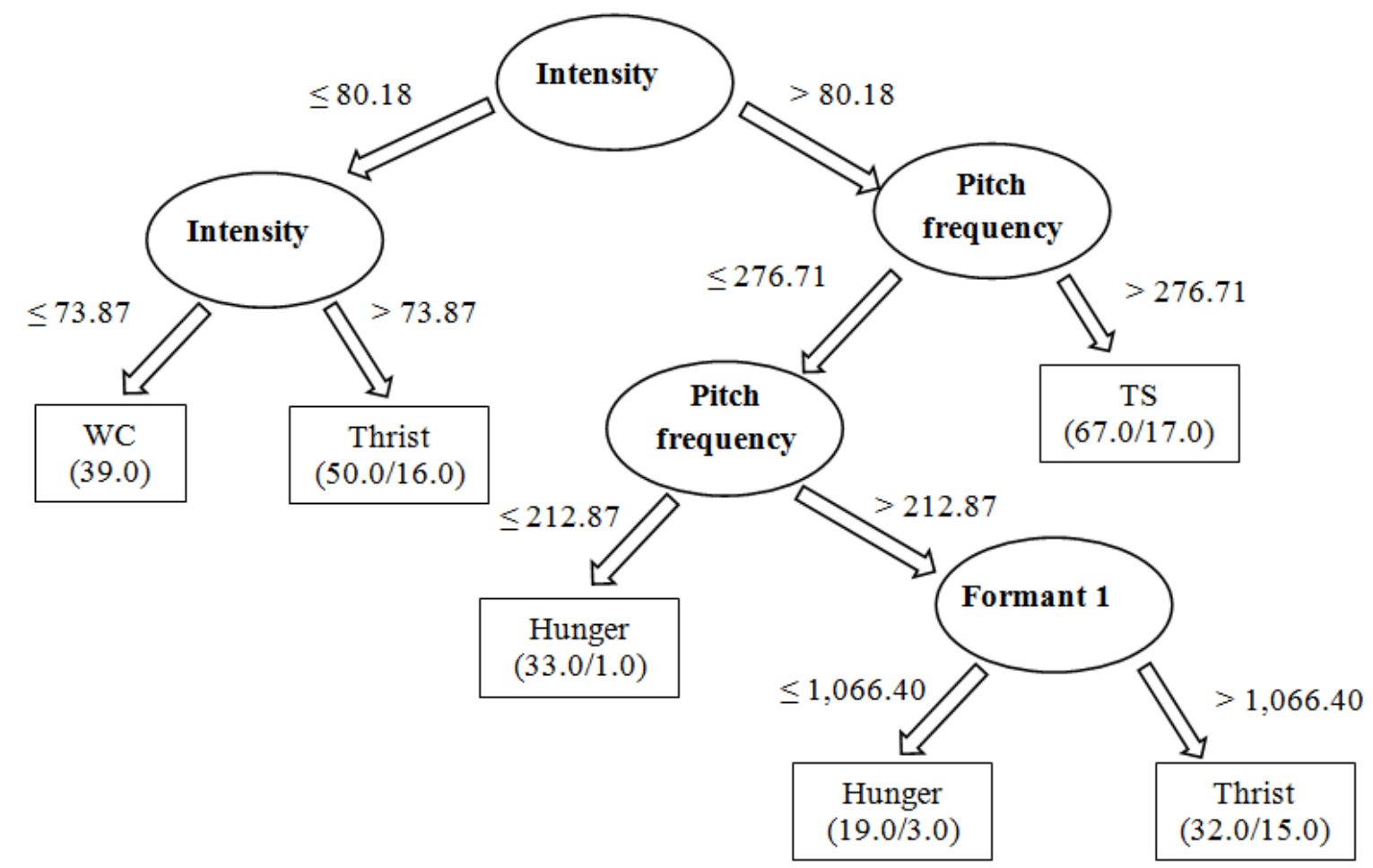

FIGURE 1. Classification of the studied stress situations using the J48 algorithm.

Piglets respond with high sound intensity cries during pain (MARX et al., 2003; LEIDIG et al., 2009), what is easily identified by humans, facilitating the sound identification for only one attribute. Responses to hunger and cold sensations during extreme exposures that may cause pain are more difficult to identify, so more attributes are needed to be used in the identification process, as indicated by SCHRADER \& TODT (1998). SAMPAIO et al. (2007) found that the noise emitted by pigs under thermal discomfort tends to increase with raised heat stress. This agrees with our findings and, also, with the pitch frequency, which determines the height of sound waves, enabling identification of heat stress.

The identification of hunger and thirst by Formant 1 was also found by SCHRADER \& TODT (1998) and DÜPJAN et al. (2008). The authors indicated that these vocal expressions are different from those related to other types of social stress, fear, and frustration. However, several authors highlight the difficulty of classifying these specific conditions, since these occur concomitantly and need more than one attribute, or combination of them, to more precisely identify the stress type (SCHRADER \& TODT, 1998; MARX et al., 2003; CORDEIRO et al., 2012).

It was not possible to identify gender by sound intensity, or to use the other studied attributes. This is different from studies on other animal species, which show that animal gender may be identified by sound signals (BALSBY \& ADAMS, 2011; MATROSOVA et al., 2011; GOGOLEVA et al., 2012).

\section{CONCLUSIONS}

A decision tree was generated to identify situations of swine hunger, thirst, and heat stress, using records of sound intensity, pitch frequency, and formant 1. 
Considering the studied attributes, it was not possible to identify animal gender by their vocalization.

\section{REFERENCES}

BALSBY, J. S. T.; ADAMS, D. M. Vocal similarity and familiarity determine response to potential flock mates in orange-fronted conures (Psittacidae). Animal Behaviour, Amsterdam, v. 81, n. 5, p.983-991, 2011.

BAPTISTA, R.I.A.; BERTANI, G.R.; BARBOSA, C.N. Indicadores do bem-estar em suínos. Ciência Rural, Santa Maria, v.41, n.10, p. 1823-1830, 2011.

CALDARA, FABIANA R.; ROSA, P. S. G.; FERREIRA, R. A.; REIS, N. M. O.; NÄÄS, I. A.; PAZ, I. C. L. A.; GARCIA, R. G.; FERREIRA, V. M. O. S. Behavior, performance and physiological parameters of pigs reared in deep bedding. Engenharia Agrícola, Jaboticabal, v.32, n.1, p. 38-46, 2012.

CORDEIRO, A. F.S.; NÄÄS, I. A.; OLIVEIRA, S. R. de M.; VIOLARO, F.; ALMEIDA, A. C. M. Efficiency of distinct data mining algorithms for classifying stress level in piglets from their vocalization. Engenharia Agrícola, Jaboticabal, v.32, n.2, p. 208-216, 2012.

DÜPJAN, S.; SCHÖN, P. PUPPE, B.; TUCHSCHERER, A.; MANTEUFFEL, G. Differential vocal responses to physical and mental stressors in domestic pigs (Sus scrofa). Applied Animal Behaviour Science, Amsterdam, v. 114, p. 105-115, 2008.

GEBERZAHN, N.; GOYMANN, W.; MUCK, C.; TEN CATE, C. Females alter their song when challenged in a sex-role reversed bird species. Behavioral Ecology and Sociobiology, Berlim, v. 64, n. 2, p 193-204, 2009.

GOGOLEVA, S. S.; VOLODIN, I. A.; VOLODINA, E. V.; KHARLAMOVA A. V.; TRUT, L. N. Effects of selection for behavior, human approach mode and sex on vocalization in silver fox. Journal of Ethology, online, 2012. Disponível em:

<http://link.springer.com/article/10.1007/s10164-012-0353-x/fulltext.html>. p. 1-6. DOI:10.1007/s10164-012-0353-x. Access: 7 dez 2012.

GRANDIN, T. The feasibility of using vocalization scoring as an indicator of poor welfare during slaughter. Applied Animal Behaviour Science, Amsterdam, v.56, n.2, p.121-128, 1998.

LEIDIG, M.S.; HERTRAMPF, B.; FAILING, K.; SCHUMANN, A.; REINER, G. Pain and discomfort in male piglets during surgical castration with and without local anesthesia as determined by vocalization and defence behaviour. Applied Animal Behaviour Science, Amsterdam, v.116, n. 2, p.174-178, 2009.

MARX, G.; HORN, T.; THIELEBEIN, J.; KNUBEL, B.; BORELL, E. Analysis of pain-related vocalization in young pigs. Journal of. Sound Vibration, Amsterdam, v. 266, n. 4, p.687-698, 2003.

MATROSOVA, V. A.; BLUMSTEIN, D. T.; VOLODIN, I. A.; VOLODINA, E. V. The potential to encode sex, age, and individual identity. Naturwissenschaften, Berlim, v.98, n.3, p.181-192, 2011.

NÄÄS, I.A.; CAMPOS, L.S.L.; BARACHO, M.S.; TOLON, Y.B. Uso de redes neurais artificiais na identificação de vocalização de suínos. Engenharia Agrícola, Jaboticabal, v. 28, p. 204-216, 2008.

RISI, N. Uso da vocalização como indicador patológico em leitões na fase de maternidade. 2010. 93f. Dissertação (Mestrado) - Escola Superior de Agricultura “Luiz de Queiroz”, Universidade de São Paulo, Piracicaba, 2010.

ROLLER, W.L.; GOLDMAN, R.F. Response of swine to acute heat exposure. Transactions of the ASAE, St. Joseph, v.12, n.2, p.164-169, 174, 1969. 
RORIZ, M. Psicrom 1.0 - Relações Psicométricas. Universidade Federal de São Carlos, Departamento de Engenharia Civil. Programa de Pós-Graduação em Construção Civil. São Carlos, 2003.

SAMPAIO, C. A. P.; NÄÄS, I. A.; SALGADO, D. D.; MARCOS P. G.; QUEIRÓS, M. P. G. Avaliação do nível de ruído em instalações para suínos. Revista Brasileira de Engenharia Agrícola e Ambiental, Campina Grande, v.11, n.4, p. 436-440, 2007.

SCHRADER, L.; TODT, D. Vocal quality is correlated with levels of stress hormones in domestic pigs. Ethology, Berlim, v.104, n. 10, 859-876, 1998.

SPINKA, M. Social dimension of emotions and its implication for animal welfare. Applied Animal Behaviour Science, Amsterdam, v. 138, n.2, p. 170-181, 2012. 